\title{
THE EVALUATION OF ANTIOXIDANT CAPACITY OF PROPOLIS ORIGINATING FROM WESTERN ROMANIA
}

\author{
ADRIANA DĂRĂBAN ${ }^{1}$, NELI K. OLAH ${ }^{1,2}$, RAMONA F. BURTESCU ${ }^{2}$, FLAVIA PRIPON \\ FURTUNA ${ }^{2}$, DANIELA HANGANU ${ }^{3}$, IOAN SIMON ${ }^{3}$, MARIUS BOJIŢĂ ${ }^{3}$, CODRUŢA SIMONA \\ HEGHEŞ $^{3 *}$, LORENA FILIP ${ }^{3}$ \\ ${ }^{I}$ Vasile Goldis"Western University of Arad, Faculty of Pharmacy, 86 Rebreanu Street, Arad, Romania \\ ${ }^{2}$ SC PlantExtrakt SRL, 407059 Rădaia. Cluj, Romania \\ ${ }^{3}$ Iuliu Haţieganu University of Medicine and Pharmacy, Faculty of Pharmacy, Cluj-Napoca, Romania
}

*corresponding author: cmaier@umfcluj.ro

Manuscript received: September 2018

\begin{abstract}
The propolis, a resinous material produced by bees, was used from ancient times as a general panacea. The main active compounds known in propolis are the phenolic acids and flavonoids from the main class of polyphenols. This paper presents the flavonoid and phenolic acids contents evaluation by spectral (UV-Vis) methods of some propolis samples originating from two region located in the West (4 samples) and Northwest ( 3 samples) of Romania. The total flavonoid content expressed in chrysin ranges from 2.06 to $6.88 \%$ respectively the total phenolic acids content expressed in caffeic acid from 0.30 to $0.72 \%$. It was evaluated the antioxidant capacity by DPPH, TEAC, FRAP, CUPRAC and silver nanoparticle (SNPAC) methods. All studied samples have shown important antioxidant capacity, an effect that could not be directly correlated with the polyphenols content, but exist a similar correlation trend at the studied samples.
\end{abstract}

\section{Rezumat}

Propolisul este un material răşinos produs de albine, utilizat încă din antichitate ca un panaceu. Componenții activi principali ai propolisului fac parte din clasa polifenolilor, fiind reprezentați de acizii fenolici și flavonoide. Lucrarea prezintă evaluarea spectrală (UV-Vis) a conținutului de acizi fenolici și flavonoide din probe de propolis recoltate din vestul și nord-vestul României. Conținutul de flavonoide totale exprimate în crisină se situează între 2,06 și 6,88 \%, iar cel de acizi fenolici totali exprimați în acid cafeic între 0,30 și $0,72 \%$. Deoarece polifenolii sunt principalii compuşi responsabili de capacitatea antioxidantă a produselor naturale s-a evaluat această capacitate prin metodele DPPH, TEAC, FRAP, CUPRAC respectiv cu nanoparticule de argint (SNPAC). Toate probele studiate au demonstrat o capacitate antioxidantă semnificativă, acest efect neputând fi corelat direct cu conținutul de polifenoli, dar s-a observat o tendință similară a corelațiilor.

Keywords: antioxidant capacity, polyphenols, propolis.

\section{Introduction}

The resinous material, named propolis and produced by honeybees (Apis mellifera L.) to defend the hive, is a powerful therapeutic product. Starting from the compounds collected from various plant sources, the bees produce a solid product with gummy aspect, with ocker-yellow, reddish, brown or greenish colour [18]. Due by its wide therapeutic benefits, propolis became, during the time, one of the basic product of apitherapy.

The composition of this resinous material depends on factors like the climatic conditions and the vegetation of the harvesting area. Besides the resins and waxes, in propolis were identified essential oil, polyphenols, sugars, aminoacids, vitamins, enzymes, mineral salts, etc. [7-9, 13]. The propolis' essential oil main components are aromatic ones, like benzyl-derivatives, vanillin, eugenol in European propolis, sesquiterpenes in Asian propolis and monoterpenes in South American propolis [4].
The polyphenols are represented by flavonoids, mostly aglycons of the glycosidic flavonoids, compounds of the plant species from which the bees collect the pollen, respectively phenolic acids, mostly hydroxybenzoic derivatives, like caffeic acid, ferulic acid or gallic acid [1]. Chrysin is the most abundant from flavonoids (2-4\%) [12]. The red type propolis was found to have the highest total phenolic acids content $(232 \mathrm{mg} / \mathrm{g})$ [2,21]. This result was observed also in the propolis of Populus species, a plant from temperate climate that is well known for their polyphenol-rich resin $[2,14]$.

Due to the high content in polyphenols, propolis has important antioxidant capacity that was investigated by many researchers. Studies showed that the active compounds were better extracted using methanol and also revealed important differences between samples obtained from varies geographical regions $[11,15]$. The complex chemical composition leads the propolis and its extracts to 
have a lot of beneficial effects. Due to its essential oil and polyphenol content, propolis has antimicrobial, antifungal, antitumoral, anti-inflammatory, hepatoprotective, antidiabetic, cardioprotective, antiangiogenic and immunomodulatory effects $[10,17,20]$. It was also used to obtain special cosmetic products shampoo, creams, etc. The polyphenols, flavonoids and caffeic acid derivatives, are responsible for its antioxidant effect.

This study presents the evaluation of the antioxidant capacity of propolis samples collected from special areas from the West and Northwest of Romania.

\section{Materials and Methods}

\section{Materials}

The propolis samples were extracted by grinding the samples and then were mixed with $70 \%$ vol. ethanol. The extraction was performed by maceration (cold extraction) using to $10 \mathrm{~g}$ of propolis $100 \mathrm{~mL}$ solvent. The mixtures were well shaken, being then kept 48 hours in dark, during which were periodically shaked. At the end, each mixture was filtered. For each sample were prepared three extracts [22].

Ethanol (96 \% vol.) was purchased from Coman Prod, Ilfov, Romania. The purified water was obtained from a Millipore-Merck Elix 100 system. Sodium acetate, aluminium chloride, methanol, natrium tungstate, phosphoric acid, sodium carbonate, 2,4,6-tripyridyl-s-triazine, $36.5 \%$ hydrochloric acid, iron chlorid, Trolox, 2,9-dimethyl1,10-phenantroline, copper chloride, ammonium acetate, $26 \%$ ammonia, silver nitrate, trisodium citrate, 2,2-diphenyl-1-picrylhydrazyl, 2,2-azinobis (3-ethyl-benzothiazoline)-6 sulfonic acid and potassium persulfate were purchased from Merck, Germany; chrysin and caffeic acid from Phytolab, Germany.

The spectrophotometric methods were performed on a Cintra 101, GBC spectrophotometer, Australia.

The propolis samples origin

The studied propolis samples were collected from various beekeepers, from the West and Northwest parts of Romania, Arad respectively Bihor counties. Four samples were collected from the West region (Arad area): AR1, AR2, AR3 and AR4; three samples were collected from Northwest counties (Bihor area) : $\mathrm{BH} 1, \mathrm{BH} 2$ and $\mathrm{BH} 3$.

The spectral determinations of total polyphenols and flavonoids respectively of antioxidant capacity

\section{Total flavonoids}

The quantitative determination of flavonoids was performed using the spectrophotometric aluminum chloride method and the results were expressed in chrysine equivalents (CE; \% mg/mL extract) [23].

Total phenolic content

The total phenolic content (TPC) of the extracts was determined by the Folin-Ciocalteu method with some modifications. The absorbance was measured at $725 \mathrm{~nm}$ and the results were expressed in caffeic acid equivalents (CAE; \% mg/mL extract) [23].

Antioxidant capacity determinations

FRAP method uses the reduction of the ferric ion to the ferrous ion in a complex formed with the radical 2,4,6-tripyridyl-s-triazine. According to the concentration of antioxidant compounds in the sample, the colour of the complex changes and the absorbance is measured at $593 \mathrm{~nm}$. The results are expressed as $\mathrm{mM}$ Trolox equivalent/100 $\mathrm{mL}$ extract, on the basis of a calibration curve using Trolox as standard $[5,19]$.

CUPRAC method assesses the reduction of the copper ion (II) to the copper iron (I) in the complex formed with neocupreine (2,9- dimethyl-1,10phenantroline), which determines a change in the colour from light green to reddish-orange. The colour change is correlated with the antioxidant capacity by measuring the absorbance at $450 \mathrm{~nm}$. The calibration curve was plotted using Trolox as standard and the results are expressed as $\mathrm{mM}$ Trolox equivalent/100 $\mathrm{mL}$ extract [16].

SNPAC method uses the spherical silver nanoparticles obtained from silver nitrate by reducing of silver (I) ions by antioxidants and using as surface stabilizer the trisodium citrate. The fine colloidal silver nanoparticles, suspended in solution, occur in the presence of the sample's antioxidants. The absorbance is correlated to the color change from pale yellow to brown and was measured at 423 $\mathrm{nm}$. The calibration curve for standard is plotted using Trolox as standard. Results are expressed as $\mathrm{mM}$ Trolox equivalent/100 $\mathrm{mL}$ extract [16].

$D P P H \bullet$ scavanger method is an antioxidant assay based on electron-transfer. The decrease in the absorbance, after interaction of $\mathrm{DPPH} \cdot$ with antioxidant compounds, was measured at $517 \mathrm{~nm}$. The antiradical activity is expressed as $\mathrm{IC}_{50}(\mu \mathrm{L}$ extract), the concentration of extract required to determine 50\% DPPH inhibition, using the following formula for determination the inhibition percentage: $\% I=\left(A_{r}-A_{s}\right) * 100 / A_{r}$. where $A_{r}$ is the absorbance of reference solution and $A_{s}$ is the absorbance of the solutions with the samples $[6,19]$.

TEAC assay is based on the ability of an antioxidant to reduce the 2,2-azinobis-(3-ethyl-benzothiazoline6- sulfonic acid) free cationic radical (ABTS ++ ), which is obtained by adding a potassium persulfate solution. Spectrophotometric determination was performed at $734 \mathrm{~nm}$. The percentage of inhibition is expressed as IC50 ( $\mu \mathrm{L}$ extract) and it was compared with a Trolox standard $[3,19]$.

Statistical analysis

For all samples were made three individual determinations and the final results are the mean value of these. The results are given as mean value \pm SD (standard deviation). The graph and the calculations were performed using the Excel software program. 


\section{Results and Discussions}

The determination of total phenolics and total flavonoids contents. In Figure 1 are presented the calibration curves of chrysin and caffeic acid obtained by UV-Vis spectrophotometry to determine the total flavonoids respectively the total phenolic acids. These analysis results can be observed in table I.

Table I

The total flavonoids content expressed in chrysin and total phenolic acids content expressed in caffeic acid

\begin{tabular}{|c|c|c|}
\hline \multirow{2}{*}{ Samples } & \multicolumn{2}{|c|}{ Concentration, \% (g/mL) } \\
\cline { 2 - 3 } & Total flavonoids expressed in chrysin, CE & Total phenolic acids expressed in caffeic acid, CAE \\
\hline Calibration curves & $\mathrm{A}=0.0023^{*} \mathrm{c}-0.0562$ & $\mathrm{~A}=0.1098^{*} \mathrm{c}+0.0157$ \\
\hline correlation factor & 0.9952 & 0.9997 \\
\hline AR1 & $1.57 \pm 0.037$ & $0.30 \pm 0.006$ \\
\hline AR2 & $2.53 \pm 0.045$ & $0.33 \pm 0.029$ \\
\hline AR3 & $4.28 \pm 0.041$ & $0.46 \pm 0.026$ \\
\hline AR4 & $6.88 \pm 0.115$ & $0.72 \pm 0.041$ \\
\hline BH1 & $2.06 \pm 0.031$ & $0.49 \pm 0.004$ \\
\hline BH2 & $3.01 \pm 0.042$ & $0.54 \pm 0.011$ \\
\hline BH3 & $3.52 \pm 0.189$ & $0.63 \pm 0.082$ \\
\hline
\end{tabular}

where A means absorbance and c means concentration.
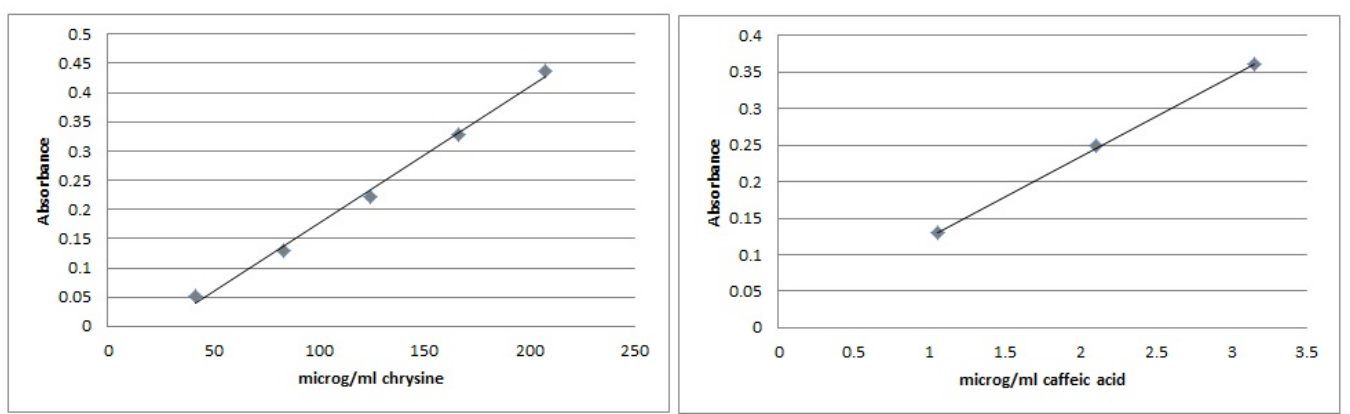

Figure 1

The calibration curves of chrysin and caffeic acid by UV-Vis spectrophotometry

The determination of antioxidant capacity

The antioxidant capacity was evaluated using five different spectrophotometric methods: DPPH, TEAC, FRAP, CUPRAC and SNPAC. In case of the first two methods DPPH and TEAC the $\mathrm{IC}_{50}$ values were calculated (Table II). The antioxidant capacity determined by the other three methods was expressed as $\mu \mathrm{M}$ Trolox equivalent $/ 100 \mathrm{~mL}(\mu \mathrm{M} \mathrm{TE} / 100 \mathrm{~mL})$ of propolis extract (Table II). In Figure 2 are presented the curves obtained by each method for Trolox respectively in Table II the correspondent equations and correlation factors.
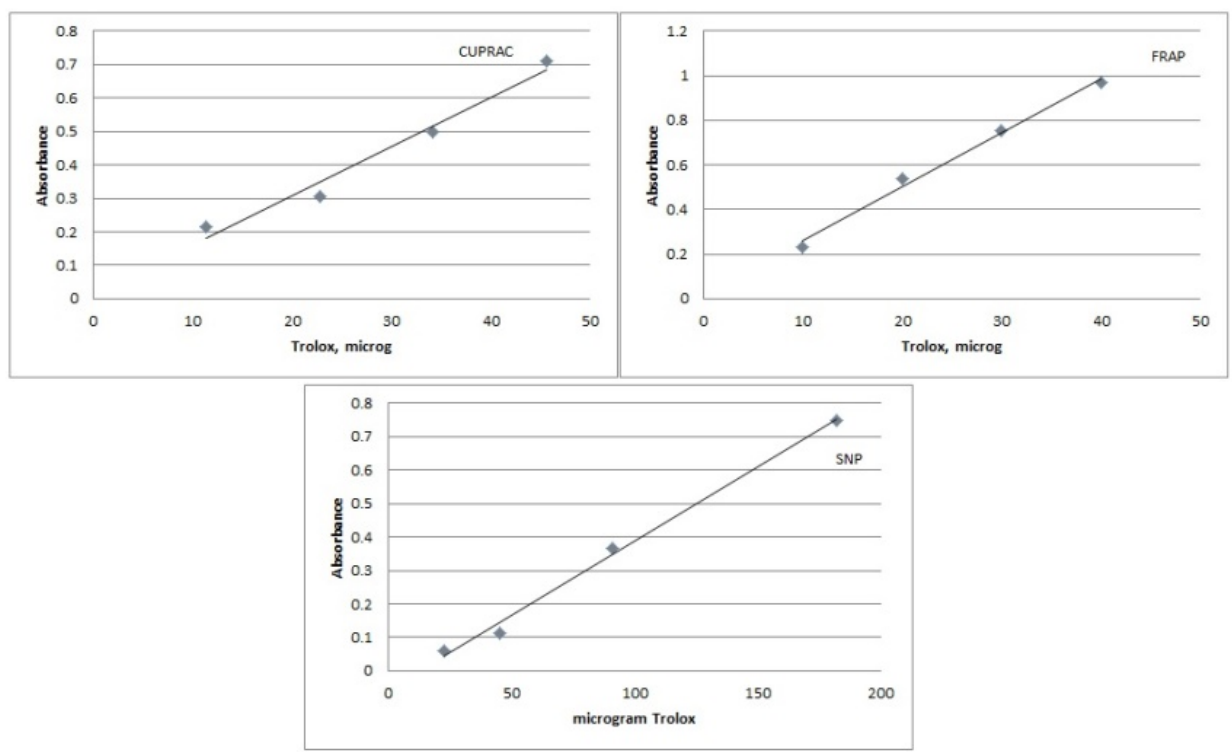

Figure 2

The Trolox antioxidant capacity evaluation curves 
Table II

The antioxidant capacity determinations results

\begin{tabular}{|c|c|c|c|c|c|}
\hline Samples & $\mathrm{DPPH}, \mathrm{IC}_{50}, \mu \mathrm{L}$ & $\begin{array}{l}\text { TEAC, } \\
\mathrm{IC}_{50, \mu \mathrm{L}}\end{array}$ & $\begin{array}{c}\text { FRAP, } \\
\mu \mathrm{M} \text { TE/ } 100 \mathrm{~mL}\end{array}$ & $\begin{array}{c}\text { CUPRAC, } \\
\mu \mathrm{M} \text { TE/ } 100 \mathrm{~mL}\end{array}$ & $\begin{array}{c}\text { SNP, } \\
\mu \mathrm{M} \text { TE/100 mL }\end{array}$ \\
\hline Trolox equation & \multirow{2}{*}{50.4} & \multirow{2}{*}{17.4} & $\begin{array}{c}\mathrm{A}=0.0241 * \mathrm{c}+ \\
0.0186\end{array}$ & $\begin{array}{c}\mathrm{A}=0.0148^{*} \mathrm{c}+ \\
0.0112\end{array}$ & 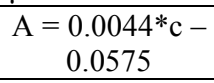 \\
\hline correlation factors & & & 0.9920 & 0.9733 & 0.9943 \\
\hline AR1 & $3.50 \pm 0.005$ & $0.80 \pm 0.001$ & $5362 \pm 20$ & $12404 \pm 64$ & $15731 \pm 48$ \\
\hline AR2 & $3.50 \pm 0.005$ & $0.81 \pm 0.001$ & $8956 \pm 11$ & $35721 \pm 57$ & $31321 \pm 71$ \\
\hline AR3 & $3.70 \pm 0.004$ & $0.83 \pm 0.002$ & $5196 \pm 12$ & $12378 \pm 50$ & $24984 \pm 58$ \\
\hline AR4 & $1.90 \pm 0.003$ & $0.67 \pm 0.001$ & $7420 \pm 15$ & $22267 \pm 49$ & $55633 \pm 77$ \\
\hline BH1 & $1.90 \pm 0.004$ & $0.67 \pm 0.001$ & $7311 \pm 20$ & $21641 \pm 65$ & $61953 \pm 77$ \\
\hline $\mathrm{BH} 2$ & $1.70 \pm 0.005$ & $0.64 \pm 0.001$ & $6567 \pm 17$ & $19221 \pm 44$ & $37364 \pm 45$ \\
\hline $\mathrm{BH} 3$ & $1.30 \pm 0.006$ & $0.59 \pm 0.001$ & $9379 \pm 14$ & $29349 \pm 67$ & $54516 \pm 57$ \\
\hline
\end{tabular}

where A means absorbance and c means concentration.

The correlation between the total content of flavonoids in the samples of the two counties and

antioxidant capacity are presented in Figure 3.

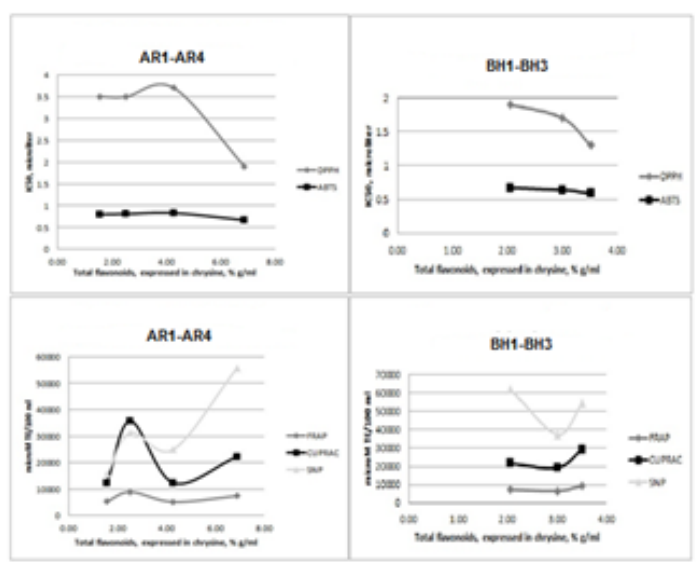

Figure 3

The correlations between total flavonoids content and antioxidant effect

The correlation between the results obtained by DPPH and TEAC (ABTS) methods respectively the results of FRAP and CUPRAC methods are presented in Figure 4, the correlation factors being 0.9911 respectively 0.9103 .
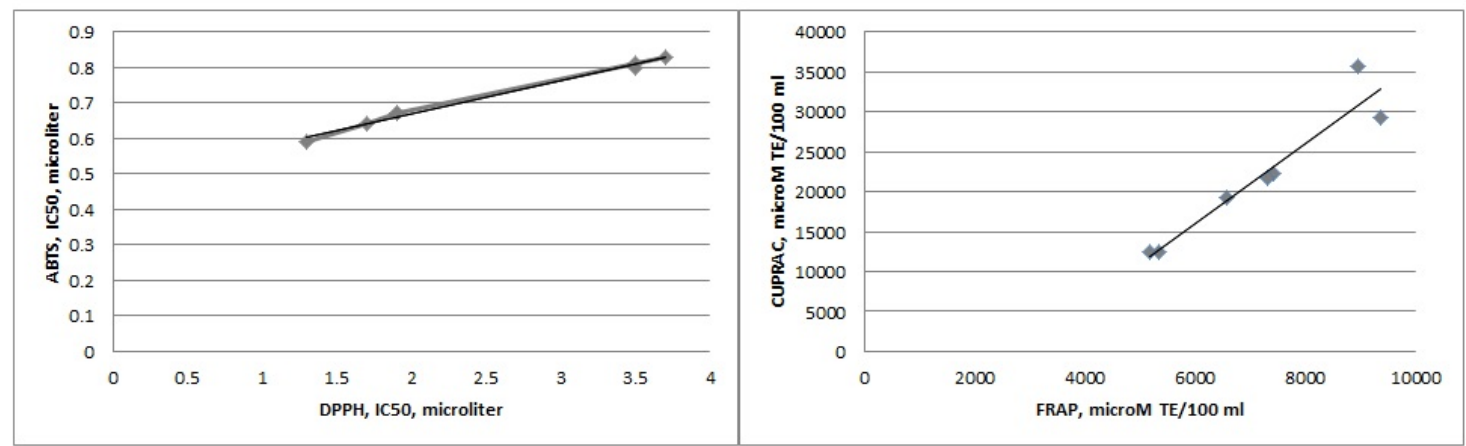

Figure 4

The correlations between the different antioxidant capacity evaluation methods

According to the results of UV-Vis spectrophotometric determinations the most concentrated in flavonoids and phenolic acids is the sample AR4. The flavonoids content is higher than those of phenolic acids in all samples. The total flavonoids concentration of samples AR3 and AR4 is higher than those determined in methanolic extracts studied by different researchers. Miguel et al. 2014, establish that methanol is more effective than water in extracting total polyphenols (2.93$8.76 \mathrm{mg} / \mathrm{mL}$, respectively $0.93-2.81 \mathrm{mg} / \mathrm{mL}$ ). Flavones and flavonols are also better extracted 
with methanol $(1.28-2.76 \mathrm{mg} / \mathrm{mL})$ than with water (0.031-0.019 mg/mL).

The results of antioxidant capacity evaluation show us that the propolis samples BH1-3 have the most powerful antioxidant activity. The sample AR4, with the highest flavonoids and phenolic acids contents, has also one of the highest antioxidant capacities from the studied samples. Miguel et al. 2014 found the free radical scavenging activity by ABTS is $\mathrm{IC}_{50}=0.006-0.036 \mathrm{mg} / \mathrm{mL}$, by $\mathrm{DPPH}$ is $\mathrm{IC}_{50}=0.007-0.069 \mathrm{mg} / \mathrm{mL}$ in methanolic extracts. The Italian and Russian propolis show similar values characterized by high antioxidant capacity $(\mathrm{IC} 50<1 \mathrm{mg} / \mathrm{L})$. The Brazilian propolis' $\mathrm{IC}_{50}$ values are from about 2 to $20 \mathrm{mg} / \mathrm{L}$, being 4 to 40 times higher than the average values observed at European samples, knowing that a higher $\mathrm{IC}_{50}$ value means a lower antioxidant power. In particular, while $\mathrm{IC}_{50}$ values of Italian and Russian propolis are comparable (0.3 - $0.6 \mathrm{mg} / \mathrm{L})$, Brazilian samples display high variability: propolis from the Pantanal region differs from the other because of them high $\mathrm{IC}_{50}$ values $(12-19 \mathrm{mg} / \mathrm{L})$, followed by samples from São Paulo characterized by intermediate $\mathrm{IC}_{50}$ values $(2.4-4.2 \mathrm{mg} / \mathrm{L})$. Among these, the green type propolis seems to possess a higher antioxidant activity $(1.7 \mathrm{mg} / \mathrm{L})$, but not so different from São Paulo samples and, in any case, about four times lower than the European propolis [11]. The results obtained show a more intensive antioxidant effect of the studied propolis samples than those obtained for the propolis from Algrave [15], Russia and Brasilia. A linear correlation between the polyphenols (flavonoids and phenolic acids) content and the antioxidant capacity could not be observed. Between the two counties samples' total flavonoids content and antioxidant capacity exist a similar trend. It could be observed a linear correlation between the results obtained by DPPH and TEAC methods respectively the results of FRAP and CUPRAC methods. These results show us that it can be used for antioxidant capacity evaluation of propolis and its extracts any of these methods, because the resulted value will be similar. The lack of linear correlation between the polyphenols content and antioxidant effect show that not just the phenolic acids and flavonoids contribute to this, but also other bioactive compounds, from the complex composition of propolis, are important for this effect.

\section{Conclusions}

Romania was one of the first countries that promoted the propolis study, but this paper is the first that report the correlation between the identified components and antioxidant capacity of the propolis originating from the west part of country.

This study demonstrates that the propolis from west of Romania have high polyphenolic content and important antioxidant capacity. The results shown higher values as those reported for propolis originating from Europe or Brasilia. These results propose the propolis collected from this part of Romania to be used in food, cosmetic and pharmaceutical fields.

Because propolis is a natural product obtained by bees from the resins collected from different species, the vegetation from the bees harvesting areas influenced the chemical composition of propolis samples originating from different places. The presented methods could be used for a more complete quality evaluation of propolis. Because this study have shown that not only the polyphenols are responsible for the antioxidant effect, the use of one from DPPH and TEAC respectively one of FRAP and CUPRAC methods for evaluate the antioxidant capacity could be very helpful in the propolis quality evaluation near the compositional evaluation by chromatographic and spectral methods. In this way the quality evaluation will show also the potential efficiency of the propolis, a natural product with complex chemical composition.

\section{References}

1. Abubakar MB, Abdullah WZ, Sulaiman SA, Ang BS, Polyphenols as key players for the antileukaemic effects of propolis. Evidence Based Complementary and Alternative Medicine, 2014; 2014: 1-11.

2. Ahn MR, Kumazawa S, Hamasaka T, Bang KS, Nakayama T, Antioxidant activity and constituents of propolis collected in various areas of Korea. Journal of Agricultural and Food Chemistry, 2004; 52: 7286-7292.

3. Arnao MB, Cano A, Acosta M, The hydrophilic and lipophilic contribution to total antioxidant activity. Food Chemistry, 2001; 73: 239-244.

4. Bankova V, Popova M, Trusheva B, Propolis volatile compounds: chemical diversity and biological activity: a review. Chemistry Central Journal, 2014; 8: 28.

5. Benzie IFF, Strain JJ, The ferric reducing ability of plasma (FRAP) as a measure of "antioxidant power": the FRAP assay. Analytical Biochemistry, 1996; 239: 70-76.

6. Brand-Williams W, Cuvelier ME, Berset C, Use of a free radical method to evaluate antioxidant activity. Lebensmittel Wissenschaft und Technologie, 1995; 28: 25 .

7. Cogneac H, Vlaia L, Olariu I, Vlaia V, Lupuleasa D, Popoiu C, Experimental researches for standardization of hidroalcoholic extracts of propolis from West region of Romania. Farmacia, 2014; 62(2): 400-412.

8. Croci AN, Cioroiu B, Lazar D, Corciova A, Ivanescu B, Lazar MI, HPLC evaluation of phenolic and polyphenolic acids from propolis. Farmacia, 2009; 57(1): 52-57.

9. Croci AN, Lazar D, Potorac L, Corciova A, Ivanescu B, Lazar MI, Spectrophotometric determination of 
flavonic compounds from propolis. Farmacia, 2009; 57(1): 104-108.

10. Daleprane JB, Abdalla DS, Emerging Roles of Propolis: Antioxidant, Cardioprotective, and Antiangiogenic Actions. Evidence Based Complementary and Alternative Medicine, 2013; 2013: 1-8.

11. Fabris S, Bertelle M, Astafyeva O, Gregoris E, Zangrando R, Gambaro A, Pace Pereira Lima G, Stevanato R, Antioxidant Properties and Chemical Composition Relationship of Europeans and Brazilians Propolis. Pharmacology \& Pharmacy, 2013; 4: 46-51.

12. Gardana C, Scaglianti M, Pietta P, Simonetti P, Analysis of the polyphenolic fraction of propolis from different sources by liquid chromatographytandem mass spectrometry. Journal of Pharmacological and Biomedical Analysis, 2007; 45(3): 390-399.

13. Ghisalberti EL, Jeffries PR, Lanteri R, Matisons J, Constituents of propolis. Experientia, 1978; 34(2): 157-158.

14. Kumazawa S, Hamasaka $\mathrm{T}$, Nakayama $\mathrm{T}$, Antioxidant activity of propolis of various geographic origins. Food Chemistry, 2004; 84(3): 329-339.

15. Miguel MG, Nunes S, Dandlen SA, Cavaco AM, Antunes MD, Phenols, flavonoids and antioxidant activity of aqueous and methanolic extracts of propolis (Apis mellifera L.) from Algarve, South Portugal. Food Science and Technology (Campinas), 2014; 34 (1): 16-23.
16. Ozyurek M, Gungor N, Baki S, Guclu K, Apak R, Development of a silver nanoparticle-based method for the antioxidant capacity measurement of polyphenols. Analytical Chemistry, 2012; 84(18): 8052-8059.

17. Premratanachai $\mathrm{P}$, Chanchao $\mathrm{C}$, Review of the anticancer activities of bee products. Asian Pacific Journal of Tropical Biomedicine, 2014; 4(5): 337344.

18. Salatino A, Weinstein Teixeira E, Negri G, Message $\mathrm{D}$, Origin and Chemical Variation of Brazilian Propolis. Evidence Based Complementary and Alternative Medicine, 2005; 2(1): 33-38.

19. Thaipong K, Boonprakob U, Crosby K, CisnerosZevallos L, Hawkins Byrne D, Comparison of ABTS, DPPH, FRAP, and ORAC assays for estimating antioxidant activity from guava fruit extracts. Journal of Food Composition and Analysis, 2006; 19: 669-675.

20. Wagh VC, Propolis: A Wonder Bees Product and Its Pharmacological Potentials. Advances in Pharmacological Sciences, 2013; 2013: 1-11.

21. Woisky RG, Salatino A, Analysis of propolis: some parameters and procedures for chemical quality control. Journal of Apicultural Research, 1998; 37(2): 99-105.

22. *** European Pharmacopoeia, 9th edition, EDQM, 2018.

23. *** Romanian Pharmacopoeia, X Ed., Medicală Publishing House, Bucharest, 1993; 393 (available in Romanian). 